\title{
Productivity Enhancement of Solar Still with PV Powered Heating Coil and Chamber Step-Wise Basin
}

\author{
Salah Abdallah ${ }^{1}$ \\ 1 Mechanical and Industrial Engineering Department, Applied Science Private University, Amman, Jordan \\ e-mail: salahabdalah@asu.edu.jo
}

\begin{abstract}
There is a strong need to improve the productivity of single slope solar still. PV generator powered electrical heater and chamber step-wise design were introduced to the conventional solar still. An experimental study was performed to investigate the effect of adding the above mentioned modifications on the output parameters of the modified solar still. The inclusion of PV-powered heating coil and chamber step-wise design enhanced the productivity of distiller by up to $1098 \%$.
\end{abstract}

Keywords: solar still, chamber step-wise design, heating coil, PV.

\section{INTRODUCTION}

The supply of clean water is a basic human necessity along with food and air. Potable water is a precious source, which is rapidly becoming scare in many parts of the world. Solar distillation is one of the most important methods of utilizing solar energy for the supply of pure water to communities. Single slope solar still can be considered as one of the cheapest solutions for purifying saline water which is suitable for the Middle East and Africa because of its low cost and ease of maintenance [Goosen et al. 2000]. Intensive reviews on the use of different types of distillers and solar collectors were reported in [Kalogirou 2004, Badran and Al-Tahaineh 2005, Al-Hayek and Badran 2004, Joseph et al. 2005, Tanaka and Nakatake 2006]. The effect of using different absorbing materials in solar distillers to improve the productivity of pure water is given in [Akash et al. 1998, Akash et al. 2000, Nijmeh et al. 2005]. Mathematical modeling of solar stills was introduced by different works, such as [Tiwari 2002, Tiwari et al. 1997, Tripathi and Tiwari 2006, Yadav and Yadav 2004, Nafey et al. 2007]. In these works, the heat transfer analysis and energy balance analysis are presented. Badran and Abu-Khader [2007] conducted an experimental study on a single slope solar still under Jordanian climatic conditions and then presented a detailed theoretical heat transfer analysis. Abdallah et al. [2008] introduced design modifications to the conventional solar still, involving the installation of reflecting mirrors on all interior sides, replacing the flat basin by a step-wise basin, and by coupling the tracking system. The addition of internal mirrors improved the still productivity up to $30 \%$, while the step-wise design of basin improved the thermal performance up to $180 \%$ and the coupling of step-wise basin with single axis sun-tracking system enhanced the performance by up to $380 \%$. Abdallah and Badran [2008] conducted experimental work to study the effect of single axis suntracking system on the performance of a single slope solar still. The comparison between the fixed and sun tracked solar still showed that the sun tracking system increased the productivity by up to $22 \%$. Sulaiman and Tarawneh [2007] studied the effect of water depth in the basin on the water productivity. The obtained results showed that the decreased water depth has a significant effect on the increased water productivity. Salthyamurthya et al. [2014] studied the effect of water mass on the performance of triangular pyramid solar still with or without latent heat energy storage. They found that there is an increase of about 
$35 \%$ in the production of fresh water with latent heat energy storage than in the case of a solar still without it. Additionally, it was found that during the off shine period, the fresh water produced from the still is higher compared to higher water mass.

El-Agouz [2014] suggested a modification of a stopped solar still with water circulation using a feeding water tank filled with salt water and sea water. The results of the experimentation show that the performance of the modified step-wise still is higher than that for conventional one by up to $43 \%$ and $48 \%$ for sea water and salt water with black absorber respectively, and, $47 \%$ and $53 \%$ for salt water and sea water with cotton, respectively. Jitsuno and Hambe [2012] suggested a vacuum distillation system for purification of well water and desalination of sea water. The suggested system can produce salt as well as pure water. The thermal efficiency of this distiller is $70 \%$ and it can produce $10 \mathrm{~kg} / \mathrm{m}^{2}$ of pure water per day. The main problem of a conventional still is that the productivity per unit area of this type of desalination systems is still relatively low. Therefore, there is a strong need to enhance the efficiency of a traditional single slope solar still. The target of the present study is to improve the productivity of traditional solar still by the addition of PV generator powered electrical heater and chamber step-wise design of basin to the conventional solar still.

\section{A MODIFIED SOLAR STILL DESIGN}

Conventional solar still works when the sun radiation starts falling through the upper surface of glass into the saline water and surrounding metal sheets. Water evaporates, and the water vapor starts condensing on the inner surface of the glass cover. The condensation of vapor is due the temperature difference between the glass cover and water vapor. The drops of water slip by gravity force on the inner side of the glass cover to its end, where it will be collected in an inclined path, and then released outside tank through the effect of gravity. The suggested modified solar still involve the same process with the addition of various system modifications which are:

1) The division of the inner water basin into three step-wise chambers. In this design the surface of saline water champers is too close to the inner side of glass cover, specially, in sunrise and sunset times.
2) Inserting an electrical heater in each chamber. These heaters are powered by a photovoltaic generator. The number of heaters is equal to the number of chambers, i.e. three. Two different solar stills, conventional solar still and modified solar still with step-wise chambers and inserted heaters were designed and constructed in the Energy Center at the Applied Science University in Amman, Jordan, to evaluate the effect of design modifications on the performance of a traditional solar still. The traditional still is designed and constructed as shown in Figure 1. The traditional still is made from cast iron. The length of base is $60 \mathrm{~cm}$ and width is $28 \mathrm{~cm}$. The maximum height of the still is $41 \mathrm{~cm}$ and the minimum height is $9.5 \mathrm{~cm}$. The inclination of glass cover is $28^{\circ}$, and the thickness of steel is $1.5 \mathrm{~mm}$. The modified solar still with step-wise chambers and inserted heaters is shown in Figure 2. This solar still is made from cast iron and consists of three chambers, each chamber has a length of $28 \mathrm{~cm}$ and width of $20 \mathrm{~cm}$. The inclination of chamber is $15^{\circ}$, and the maximum height is $41 \mathrm{~cm}$, whereas the minimum height is $9.5 \mathrm{~cm}$. The slope of glass cover is $28^{\circ}$.

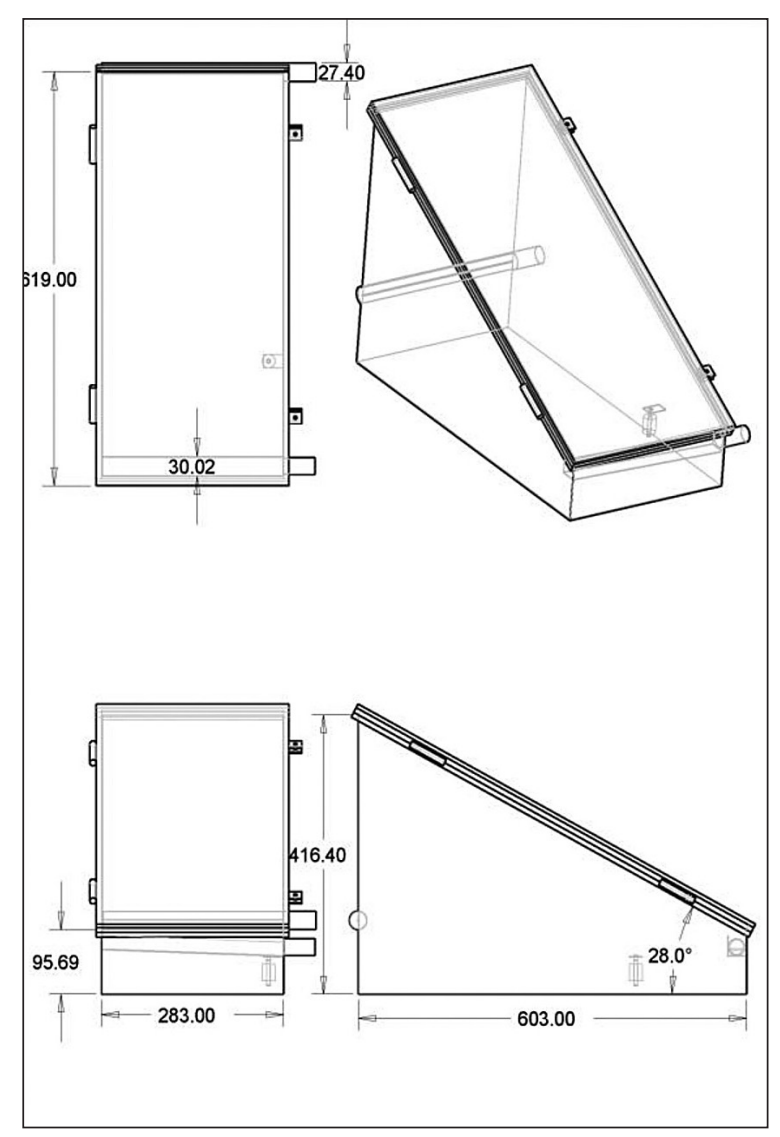

Fig. 1. Traditional solar still design and its dimensions in $\mathrm{mm}$ 


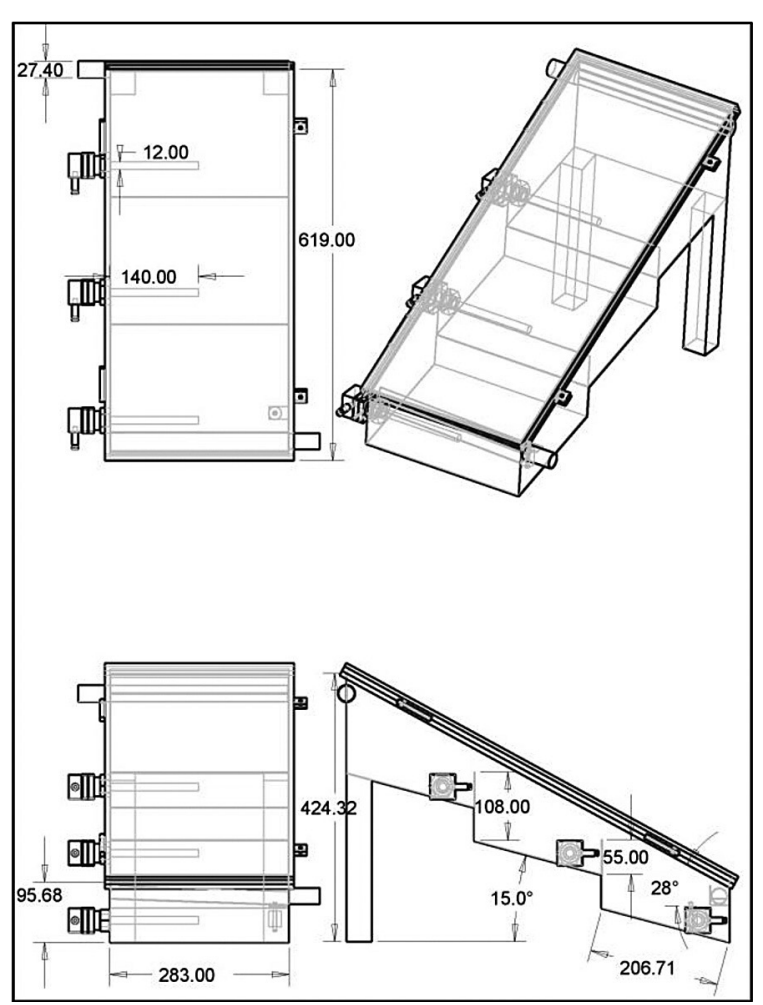

Fig. 2. Modified solar still design with its dimensions in $\mathrm{mm}$

The body of both conventional and modified solar stills is made of cast iron according to the dimensions of design process. After that both stills were painted black, and the electrical heaters were replaced in their positions as required in the modified solar still. The manufactured main bodies of two stills are shown in Figure 3.

Both stills are covered by wooden box from all sides and the bottom, leaving a distance of $2 \mathrm{~cm}$ between wood and metal sheet. This gap was filled with foam to provide an insulation to reduce the losses of heat as shown in Figure 4 and Figure 5.

The complete assembly of both stills with a supply tank and bottles of pure water is shown in Figure 6.

Electrical heater shown in Figure 7 converts the electrical power into heat. This heater is powered by a photovoltaic generator. Three heaters 24 VDC are parallel connected, and they are connected to a single photovoltaic module with the following technical characteristics: nominal voltage is $30.2 \mathrm{~V}$, and nominal current is $8.11 \mathrm{~A}$.

\section{EXPERIMENTAL PROCEDURE}

The experiments were performed on the stills, both the traditional and modified one, in different days in winter $(6,7,9,10,11$ and $12 / 12 / 2015)$, and in the period from $7 \mathrm{AM}$ to $4 \mathrm{PM}$. Readings had been taken for the ambient temperature, solar radiation, water temperature inside each still, voltage and current for electrical heaters. The readings were taken in 60 minutes time intervals for the above mentioned days. The experiments were carried out in the Energy Center at the Applied Science University in Amman, Jordan. The measuring devices were tested and calibrated before being used for taking different readings.

\section{RESULTS AND DISCUSSIONS}

The readings taken for one representative day of the above mentioned days will be discussed in the following way. The readings from 11.12.2015

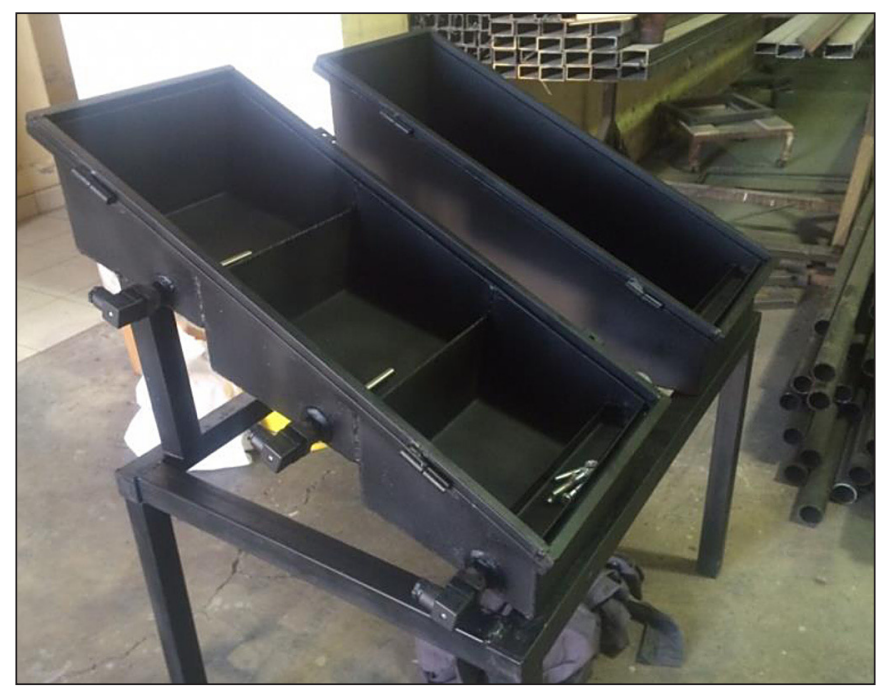

Fig. 3. Manufactured stills in the workshop of Applied Science University 


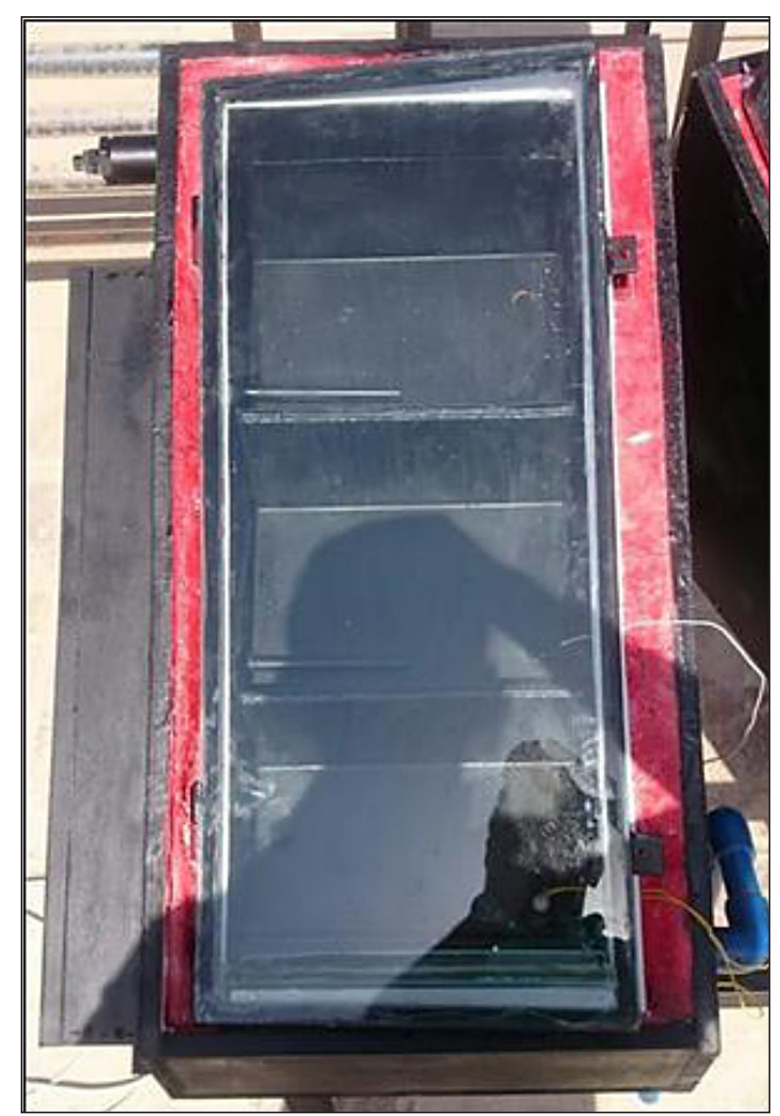

Fig. 4. Modified solar still

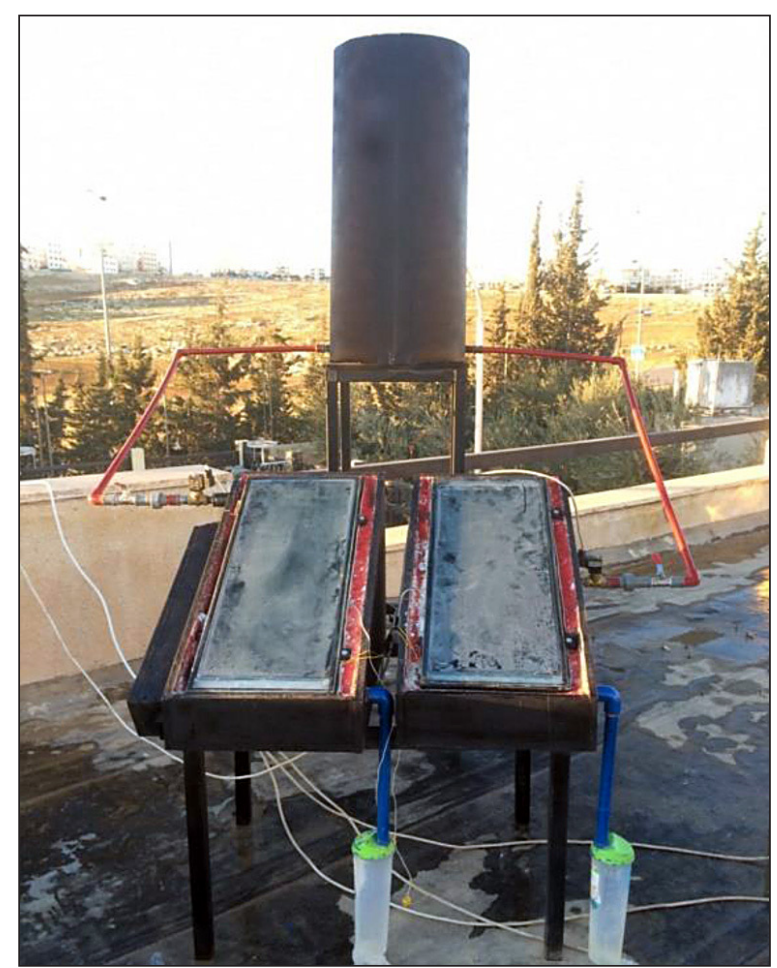

Fig. 6. The experimental setup of both stills

which was totally sunny will be shown in the form of curves. Figures $8-9$ record the solar radiation

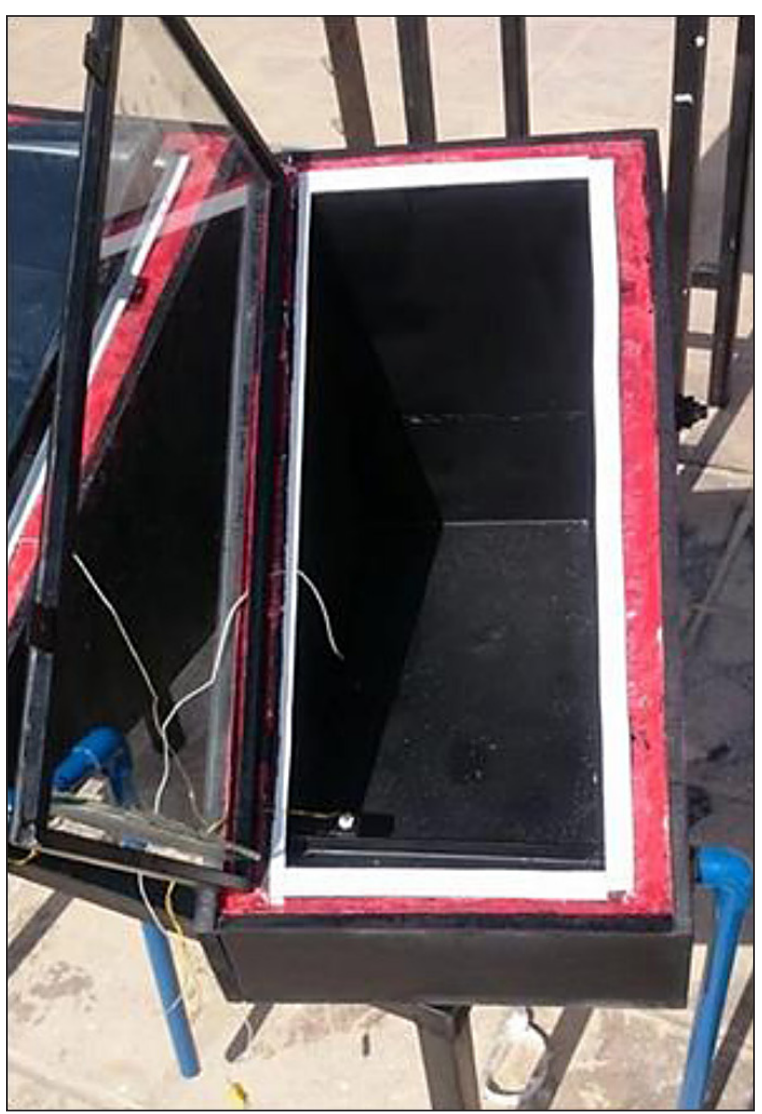

Fig. 5. Conventional solar still

variation in the function of time and ambient temperature in the function of time, respectively.

Figures 10-11 show the variation of current and power of electrical heater, respectively. Current and power increase during early hours of day until they reaches the maximum values around solar noon, proportional to highest solar radiation, then decrease as the sun sets.

The variation of the temperature inside the basin of conventional still, and the temperature inside the chamber for the modified still are shown in Figure 12.

The amount of hourly collected distilled water for both the conventional and modified stills are shown in Figure 13. It can be seen from curves that the maximum collection of distilled water was around $1 \mathrm{PM}$, because the solar radiation at this period of time is vertical with still and the ambient temperature is maximum. The effect of using design modifications on the still productivity is clear. The total collected water during day in the period from $7 \mathrm{AM}$ to $4 \mathrm{PM}$ was $0.545 \mathrm{~L} /$ day $/ \mathrm{m}^{2}$ from conventional still and $1140 \mathrm{~L} /$ day $/ \mathrm{m}^{2}$ from the modified still.

The modified still gave a higher production rate for this day, reaching $1098 \%$. The addition 


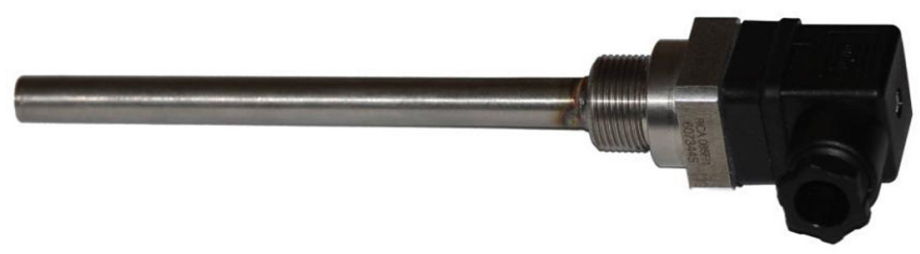

Fig. 7. Electrical heater

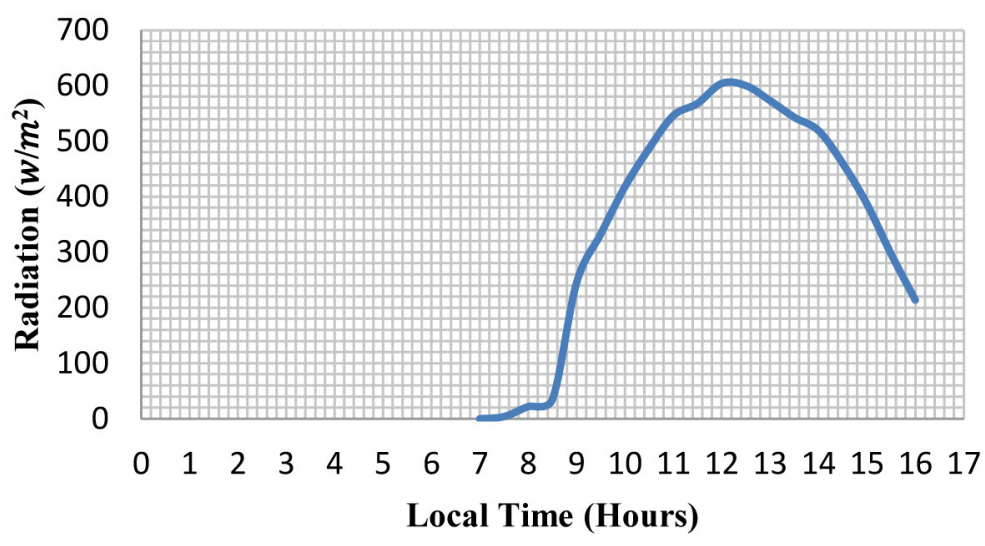

Fig. 8. Solar radiation in the function of time

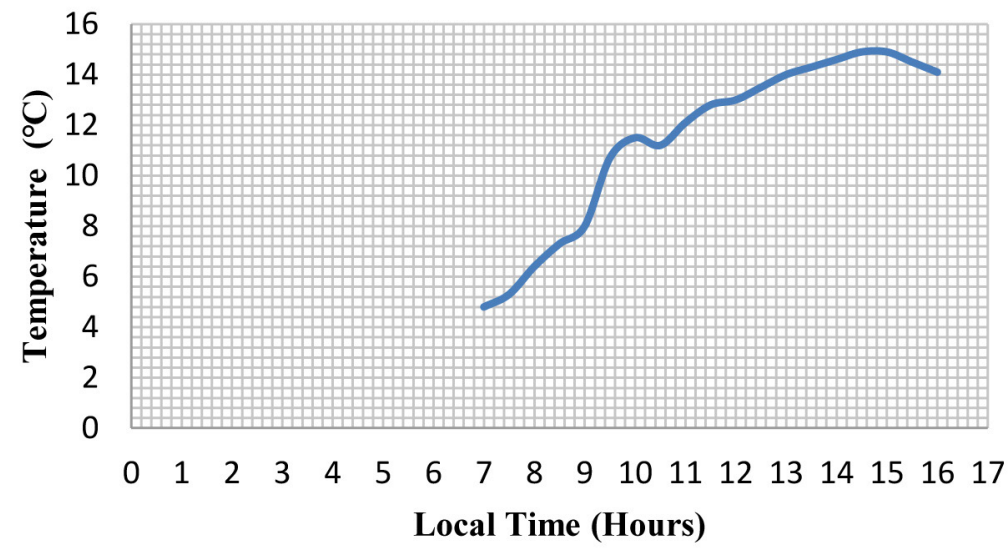

Fig. 9. Ambient temperature in the function of time

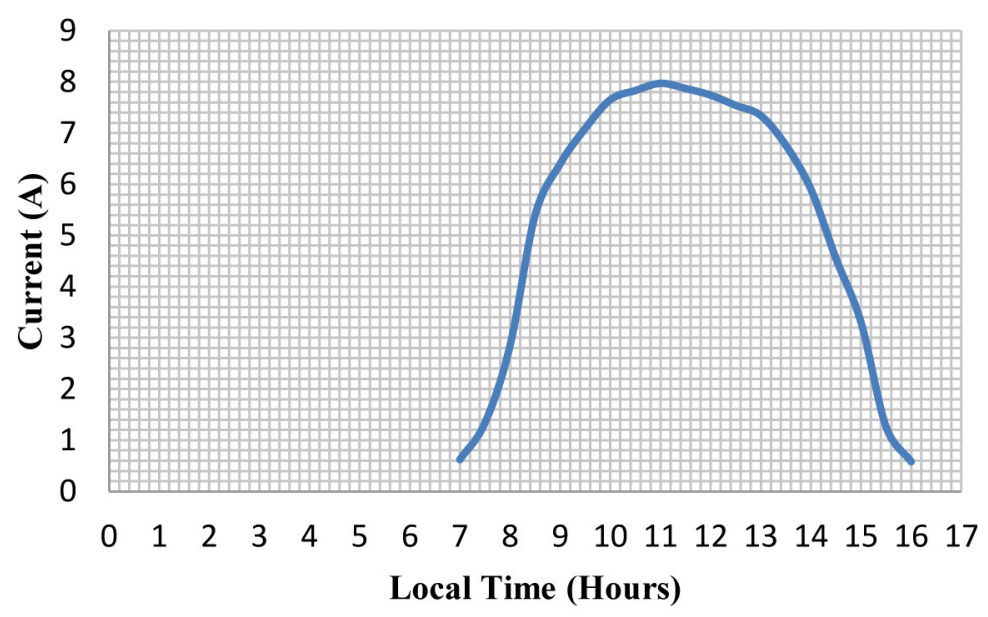

Fig. 10. The variation of current in the electrical heater 


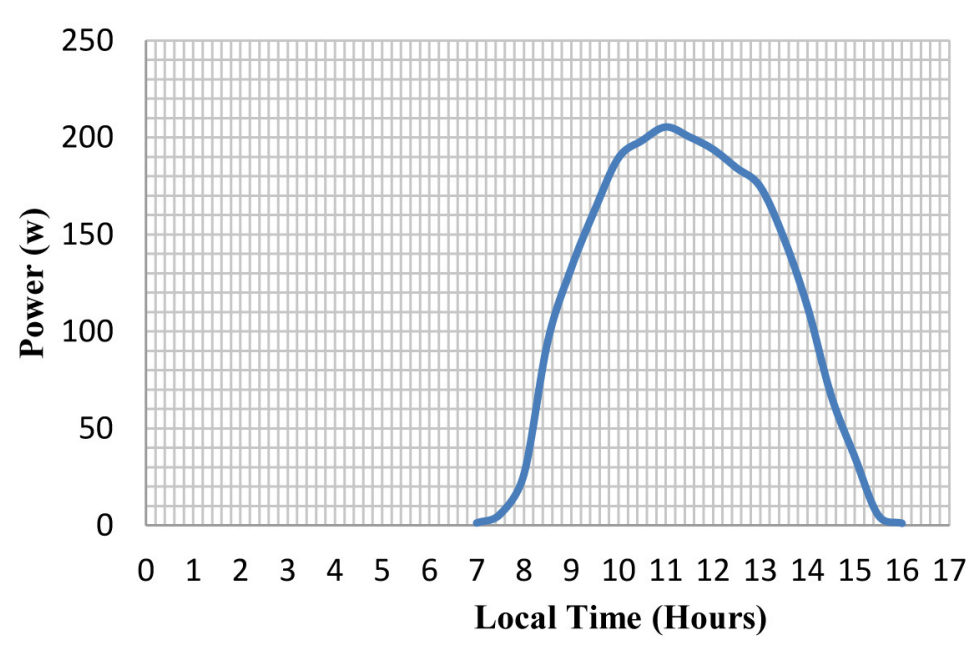

Fig. 11. The variation of power at the input of electrical heater

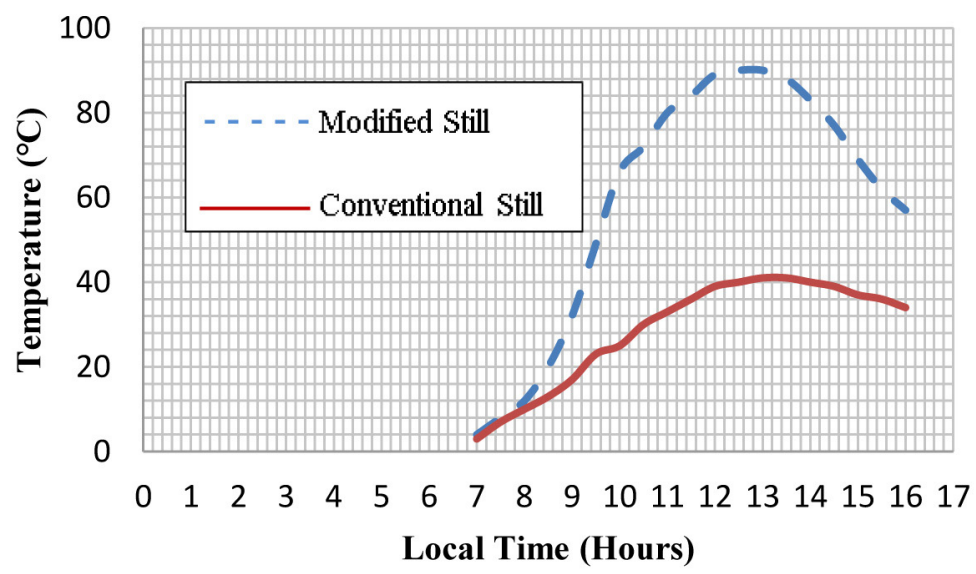

Fig. 12. The variation of inside water temperature for the conventional and modified stills

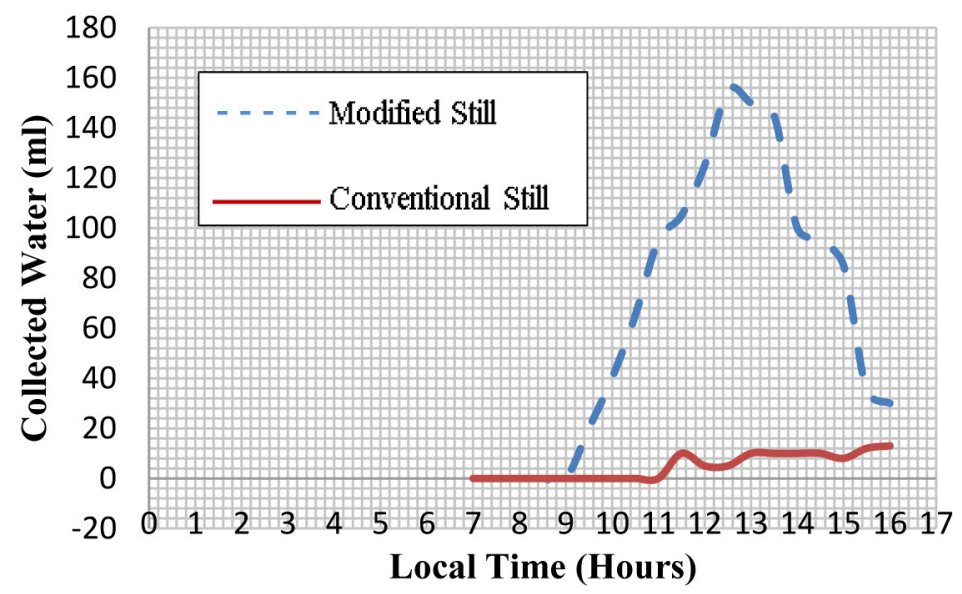

Fig. 13. The pure water collection for conventional and modified stills

of PV generator-powered electrical heater and chamber step-wise design to the conventional solar still resulted in a higher thermal performance due to different reasons: 1) The distance between the water surface in chambers and the inner side of glass cover was smaller than in a traditional still, so the kinetic energy required to raise the vapor up was lesser, and the time required to achieve this process was shorter; 2) The surface area of metal sheet exposed to solar radiation is 
huge, as compared to a conventional still, which provides higher heat and mass transfer surface; 3) The additional electrical power of heater was provided by a PV generator.

The effect of chamber step-wise design and addition of $\mathrm{PV}$ powered heater introduced to the conventional still were evident through the production gains achieved for different winter days as shown in Table 1. The average gain of a modified solar still for 6 winter days is $904 \%$ over the traditional still, due to the design modifications added in this work.

Abdallah et al. [2008] found that the inclusion of internal mirrors to the conventional still has improved the productivity by up to $30 \%$, while the step-wise basin enhanced this performance by up to $180 \%$ and the coupling of the step-wise basin with sun tracking system gave the highest thermal performance with an average of $380 \%$. Abdallah and Badran [2008] showed that the comparison between fixed and sun tracked solar still increased the productivity by up to $22 \%$. Comparing the results of this work to the results of previous works, it is clear that there is a huge difference in results in the favor of the solar still with chamber step-wise design and addition of $\mathrm{PV}$ powered heater.

\section{CONCLUSIONS}

Design modifications of the conventional solar still were suggested, involving the addition of

Table 1. Pure water collected using conventional and modified stills

\begin{tabular}{|c|c|c|}
\hline Type and date of test & $\begin{array}{c}\text { Collected pure } \\
\text { water, L/day } / \mathrm{m}^{2}\end{array}$ & Gain, \% \\
\hline $\begin{array}{l}\text { Day } 1 \text { (6 Dec. 2015): } \\
\text { - conventional still } \\
\text { - modified still }\end{array}$ & $\begin{array}{l}0.481 \\
3.774\end{array}$ & 784 \\
\hline $\begin{array}{l}\text { Day } 2 \text { (7 Dec. 2015): } \\
\text { - conventional still } \\
\text { - modified still }\end{array}$ & $\begin{array}{l}0.481 \\
4.495\end{array}$ & 934 \\
\hline $\begin{array}{l}\text { Day } 3 \text { (9 Dec. 2015): } \\
\text { - conventional still } \\
\text { - modified still }\end{array}$ & $\begin{array}{l}0.557 \\
4.375\end{array}$ & 785 \\
\hline $\begin{array}{l}\text { Day } 4 \text { (10 Dec. 2015): } \\
\text { - conventional still } \\
\text { - modified still }\end{array}$ & $\begin{array}{l}0.433 \\
3.841\end{array}$ & 887 \\
\hline $\begin{array}{l}\text { Day } 5 \text { (11 Dec. 2015): } \\
\text { - conventional still } \\
\text { - modified still }\end{array}$ & $\begin{array}{l}0.545 \\
5.985\end{array}$ & 1098 \\
\hline $\begin{array}{l}\text { Day } 6 \text { (12 Dec. 2015): } \\
\text { - conventional still } \\
\text { - modified still }\end{array}$ & $\begin{array}{c}0.527 \\
5.48\end{array}$ & 940 \\
\hline
\end{tabular}

PV-powered heating coil and chamber step-wise design. An experimental study was performed to investigate the effect of adding the above mentioned modifications on the output parameters of a modified solar still. The inclusion of PV powered heating coil and chamber step-wise design enhanced the productivity of distiller by up to $1098 \%$. The results are considerable and predictable for solar still applications. Consequently, the solar still with added design modifications can be used efficiently for pure water production in the arid zones of the world, where insolation levels are high.

\section{Acknowledgement}

The author is grateful to the Applied Science Private University, Amman, Jordan for the full financial support granted to this research project.

\section{REFERENCES}

1. Abdallah S.M. and Badran O.O. 2008. Sun-traracking system for productivity enhancement of solar still, Desalination, 220, 669-676.

2. Abdallah S.M., Badran O.O. and Abu-Khader M.M. 2008. Performance evaluation of a modified design of a single slope solar still, Desalination, 219, 222-230.

3. Akash B.A., Mohsen M.S. and Nayfeh W. 2000. Experimental study of the basin type solar still under local climate conditions, Energy Conv. Manage., 41(9), 883-890.

4. Akash B.A., Mohsen M.S., Osta O. and Elayan Y. 1998. Experimental evaluation of a single-basin solar still using different absorbing materials, Renewable Energy, 14(1-4), 307-310.

5. Al-Hayek I. and Badran O.O. 2004. The effect of using different designs of solar stills on water distillation, Desalination, 169, 121-127.

6. Badran O.O. and Al-Tahaineh H.A. 2005. The effect of coupling a flat-plate collector on the solar still productivity, Desalination, 183, 137-142.

7. Badran O.O. and Abu-Khader M.M. 2007. Evaluating thermal performance of single slope solar stills. Heat Mass Transfer, 43(10), 985-995.

8. El-Agouz S.A. 2014. Experimental investigation of stepped solar still with continuous water circulation. Energy Conversion and Management 86, 186-193.

9. Goosen M.F.A., Sablani S.S., Shayya W.H., Paton C. and Al-Hinai H., 2000. Thermodynamic and economic considerations in solar desalination, Desalination, 129, 63-89. 
10. Jitsuno T. and Hamabe K. 2012. Vacuum distillation system aiming to use solar-heat for desalination. Journal of Arid Land Studies, 22-1, 153-155.

11. Joseph J., Saravanan R. and Renganarayanan S., 2005. Studies on a single-stage solar desalination system for domestic applications, Desalination, 173, 77-82.

12. Kalogirou S.A., 2004. Solar thermal collectors and applications, Progr. Energy Combustion Sci., 30(3) 231-295.

13. Nafey A.S., Mohamad M.A., El-Helaby S.O. and Sharaf M.A., 2007. Theoretical and experimental study of a small unit for solar desalination using flashing process, Energy Conv. Manage., 48, 528-538.

14. Nijmeh S., Odeh S. and Akash B., 2005. Experimental and theoretical study of a single-basin solar sill in Jordan, Int Comm. Heat Mass Transfer, 32, 565-572.

15. Sathyamurthya R., Nagarajan P.K, Subramani J, Vijayakumar D.M., Ashraf A.K. 2014. Effect of water mass on triangular pyramid solar still using phase change material as storage medium. Energy Procedia 61, 2224-2228.
16. Suleiman M. and Tarawneh K. 2007. Effect of Water Depth on the Performance Evaluation of Solar Still. JJMIE. 1, 23-29.

17. Tanaka H. and Nakatake Y. 2006. Theoretical analysis of a basin type solar still with internal and external reflectors, Desalination, 186, 280-299.

18. Tiwari G.N., 2002. Solar Energy, Narosa Publishing House, New Delhi, India,

19. Tiwari G.N., Kupfermann A. and Agrawal S. 1997. A new design for a double-condensing chamber solar still,Desalination, 114, 153.

20. Tripathi R. and Tiwari G.N. 2004. Performance evaluation of a solar still by using the concept of solar fractionation, Desalination, 169, 69-80.

21. Tripathi R. and Tiwari G.N. 2006. Thermal modeling of passive and active solar stills for different depths of water by using the concept of solar fraction, Int. J. Solar Energy, 80(8), 956-967.

22. Yadav Y.P. and Yadav S.K. 2004, Parametric studies on the transient performance of a high-temperature solar distillation system, Desalination, 170, 251-262. 